\title{
Impact of Climate Change on Runoff Prediction in Ogbese River Watershed
}

\author{
*Obinna A. Obiora-Okeke, James R. Adewumi and Ochuko M. Ojo \\ Department of Civil Engineering, Federal University of Technology, Akure, Nigeria \\ \{oobiora-okekeljradewumilomojo\}@futa.edu.ng \\ ORIGINAL RESEARCH ARTICLE \\ Received: 29-OCT-2021; Reviewed: 04-DEC-2021; Accepted: 13-DEC-2021 \\ http://dx.doi.org/10.46792/fuoyejet.v6i4.721
}

\begin{abstract}
Increased rainfall amounts are projected in the humid southern parts of Nigeria due to climate change. The consequence of higher rainfall in future years would result to higher peak runoffs and flood stages in streams in these parts. The focus of this study is to simulate peak runoff at the outlet of Ogbese river watershed for future years of 2030, 2040, 2050 and 2060. Local twenty years (2000-2019) historical rainfall depths were used to statically downscale General Circulation Model outputs in the future for RCP 4.5 climate scenario. Downscaled rainfall depths were inputted in HEC-HMS model version 4.2 for rainfall-runoff simulation. The watershed was delineated with DEM in ArcGIS while four land use and land cover classifications were extracted with QGIS. Maximum rainfall depths projected in years 2030, 2040, 2050 and 2060 were $38.5 \mathrm{~mm} / \mathrm{hr}, 39 \mathrm{~mm} / \mathrm{hr}, 42 \mathrm{~mm} / \mathrm{hr}$ and $46 \mathrm{~mm} / \mathrm{hr}$ respectively. Peak runoff discharge simulated for RCP 4.5 climate scenario in years 2030, 2040, 2050 and 2060 are $1771 \mathrm{~m}^{3} / \mathrm{s}, 1826 \mathrm{~m}^{3} / \mathrm{s}, 1897 \mathrm{~m}^{3} / \mathrm{s}$ and $2200 \mathrm{~m}^{3} / \mathrm{s}$ respectively. This represents $24.2 \%$ increase peak discharge between 2030 and 2060. Land area delineated for the catchment is $1946.2 \mathrm{~km}^{2}$. The LULC classification areas for urban area, forest, rock outcrop and bare land are $81.59 \mathrm{~km}^{2}, 1721.84 \mathrm{~km}^{2}, 146.27 \mathrm{~km}^{2}$ and $4.11 \mathrm{~km}^{2}$ respectively. The soil types are sandy clay loam $(92.51 \%)$, sandy loam $(6.84 \%)$, and clay $(0.65 \%)$. Curve Number and Initial abstraction parameter values are 70.27 and 2.89 respectively.
\end{abstract}

Keywords- Climate change, GCM, HEC-HMS, Ogbese river, Peak runoff

\section{INTRODUCTION}

Sufficient understanding of the unpredictability of

climate variables is imperative in climate studies and water resources management as climate change has become a challenging problem in the world today (Oloruntade et al, 2020). Climate change is an event that occurs on Earth as a result of rising air temperatures (global warming), and it can affect the planet in a variety of ways such as changing rainfall patterns in several places as in recent years (Storch et al, 1993; Trenberth, 1998; Williams et al, 2003; Sipayung et al, 2018). Global warming will cause extreme rainfalls over a greater part of the earth as the amount of atmospheric water vapour that supplies water for rainfall increases in proportions to the saturation amounts at a rate of approximately $6-7 \%$ per degree rise in temperature (Allen et al, 2002; Trenberth, et al 2003; Ingram 2016; Tabari 2020).

Nigeria has been assessed to be vulnerable to the impacts of climate change (Idowu et al, 2011). According to a recent assessment, Nigeria is one of the top ten countries most vulnerable to the effects of climate change, with around $6 \%$ of its geographical area expected to be subject to extreme weather occurrences (World Bank, 2019; Okon et al, 2021). Increases in temperature, unpredictable rainfall, rising sea levels and flooding, drought and desertification, land degradation, more frequent extreme climate events, affected fresh water resources, and biodiversity loss all show that Nigeria's climate is changing (Olaniyi et al., 2013; Ebele and Emodi, 2016; Elisha et al., 2017; Haider, 2019).

*Corresponding Author

Section E- CIVIL ENGINEERING \& RELATED SCIENCES

Can be cited as:

Obiora-Okeke O. A., Adewumi J. R. and Ojo O. M. (2021): Impact of Climate Change on Runoff Prediction in Ogbese River Watershed, FUOYE Journal of Engineering and Technology (FUOYEJET), 6(4), 392-396. http://dx.doi.org/10.46792/fuoyejet.v6i4.721
The Southern parts of Nigeria with high rainfalls is currently grappling with fluctuations in the sequence of rainfall. In the savanna vegetation zone, severe heat waves are seriously confronting the area. Similarly in the Sahel region, there is a risk of losing about 30 ha of cropland per year to desertification (Obioha, 2008; Ragatoa et al., 2019). Flood modeling helps in development of early warning system and HEC-HMS model is a well suited for peak discharge generation in flood inundation mapping.

In this study, downscaled General Circulation Model (GCM) projected rainfall outputs were inputted into HEC-HMS to simulate runoff hydrograph for future years of 2030, 2040, 2050 and 2060. Meenu et al, (2013), Babel et al (2014) and Bai et al, (2019) all combined statistically downscaled GCM model outputs with HEC-HMS to generate runoff for different future climate scenarios. Meenu et al (2013) researched the effect of future climate change on hydrology of Tunga-Bhadra River watershed. They used HEC-HMS version 3.4 for rainfall-runoff simulation and linear regression based SDSM 4.2 for downscaling GCM outputs. The result of their study indicates increased precipitation and consequent runoff. Actual evapo-transpiration was projected to decrease. Bai et al (2019) developed a framework that combines HECHMS and a GCM - Coupled Model Intercomparison project phase 5 (CMIP5) - to investigate impact of future climates on flood events from precipitation of 10, 25, 50 and 100 years return period. Results of their study show that the two models can be integrated easily in making good runoff prediction under the impacts of climate change. 


\section{Methodology \\ 2.1 Description of the Study AREA}

The watershed is located between the latitudes of $6^{\circ} 40^{\circ} \mathrm{N}$ and $8^{\circ} 00^{\circ} \mathrm{N}$ of the equator and longitudes $5^{\circ} 00^{\circ} \mathrm{E}$ and $5^{\circ} 40^{\circ} \mathrm{E}$ of the Greenwich meridian (see figure 1). The river originates in Ayede-Ekiti, Ekiti State, and flows to Edo State through Ondo State. River Ogbese is a tributary to River Ose and flows downstream approximately about $265 \mathrm{~km}$ from its source to meet River Ose. The elevation of the catchment ranges within the height of $740 \mathrm{~m}$ above sea level to $37 \mathrm{~m}$ above sea level (low). Ogbese river is one of the largest rivers in both the central and northern zones of Ondo state, Nigeria (Oyelami et al., 2013, Akinbile \& Olatunji, 2018).

Farming and fishing are the main industry for people in the watershed. Cash crops which include cocoa, orange, kolanut and plantain are produced in large quantities by large numbers of farmers. The watershed area experiences regular rainfall between April and July and between September and November with the heaviest rainfall occurring in September. A brief break is experienced in August. Annual rainfall depth varies from $1,500 \mathrm{~mm}$ to $3500 \mathrm{~mm}$. The average daily temperature ranges from $22^{\circ}$ during the harmattan period (DecemberFebruary) to $32^{\circ} \mathrm{C}$ in March. The upstream watershed has an average annual relative humidity of 75 percent which is highest during the day during the rainy season when it rises to about 90 percent.

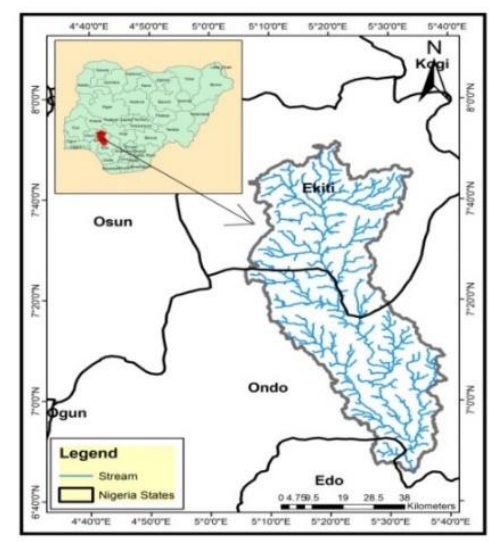

Fig. 1: Map of the study area

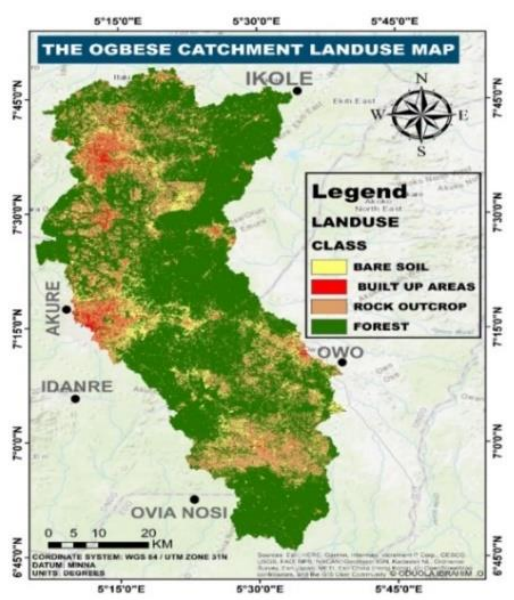

Fig. 2: Land use and land cover map of Ogbese watershed showing various land use classification

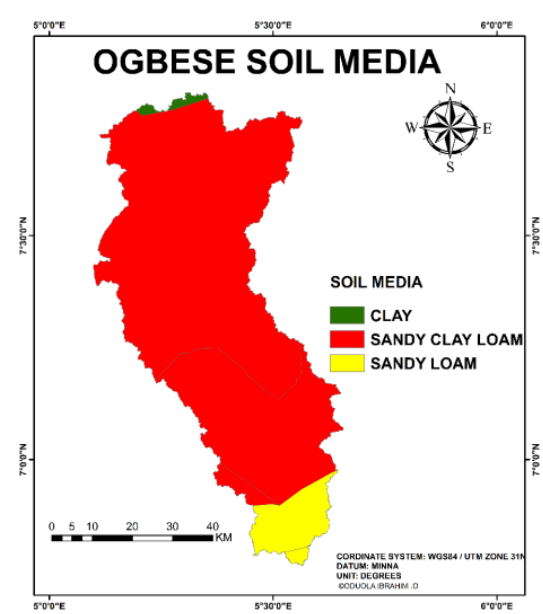

Fig. 3: Soil map of Ogbese catchment showing various soil classifications

\subsection{Data Collection}

Historical rainfall data (2000-2019) were sourced from Meteorological department Federal University of Technology, Akure. Large scale climate variables (predictors) NCEP and CanESM2 for past and future precipitation were sourced from the Canadian Climate Data and Scenarios website (https://climatescenarios.canada.ca). Statistical downscaling method was used for the projection of future climate change under Representative Concentration Pathway 4.5 (RCP 4.5). Topographic features were extracted from digital elevation model (DEM) in Aeronautical Reconnaissance Coverage Geographic Information System (ARCGIS). The DEM of the Ogbese river watershed was sourced from www.earthexplorer.usgs.gov.

Watershed level land use and land cover (LULC) map derived from the landsat-8 images 2019. The classification was achieved with the "Semi-Automatic Classification" SCP plugin on QGIS 3.10 Coruna along with NDVI techniques according to the standard classification techniques. Figure 2 show four LULC classes for the watershed; rock outcrop, urban areas, forest and bare land. A soil map of the study area is prepared and updated from the district soil map obtained from the Food and Agricultural Organization. Major soils found in the area are sandy clay loam $(92.51 \%)$, sandy loam $(6.84$ $\%)$, and clay $(0.65 \%)$ (see figure 3 ). Soils are further classified into four hydrological soil groups A, B, C and D (HSG) as per their infiltration rate.

\subsection{HEC-HMS MODEL}

HEC-HMS has three input components: (i) a basin component, which describes the different elements of the hydrologic system (sub-basins, channels, junctions, sources, sinks, reservoirs and diversions) including their hydrologic parameters and topology,(ii) a meteorologic component, which describes space and time, of the rainfall event to be simulated, and consists of time series of rainfall at specific points or areas and their relation to the hydrologic elements, (iii) control specifications component, which defines the time boundary for the rainfall event and for the calculated flow hydrograph 
(Olivera and Maidment, 1999; USACE, 2000). HMS model requires hydrological data, background maps (sub-basin and river network), LULC map, Soil map, curve number grid map, base flow, routing parameters and meteorological data. The Curve Number $(\mathrm{CN})$ parameter of the Soil Conservation Service (SCS) was computed from soil and LULC classifications of the Ogbese river watershed. The CN parameter is dependent on LULC, hydrologic soil group based on the soil texture, and antecedent moisture condition.

\subsection{STATISTICAL DOWNSCALING MODEL}

Statistical downscaling method requires establishing a statistical relationship between local climate variables and large-scale predictors and application of the product of the relationship to the output of global climate models to simulate local climate characteristics in the future (Hoar and Nychka, 2008). Downscaling is done because the outputs of GCMs are relatively coarse for application on a local or regional scale. Long term homogenous time series of data are needed from local site comparable to the GCM grid box size.

\subsection{DATA QUALITY CONTROL}

Locally observed data quality, used for the projection of future climate change on rainfall depth was assessed for any missing data. The selection of the appropriate predictor variables for the model calibration to identify empirical relationships between the gridded predictor variables and the locally observed variables was achieved by screening the variables.

\section{Results AND Discussion 3.1 LAND USE AND LAND COVER (LULC) AND SOIL CLASSIFICATIONS}

Four LULC classifications for the watershed are urban area, forest, rock outcrop and bare land and the have the following areas $81.59 \mathrm{~km}^{2}, 1721.84 \mathrm{~km}^{2}, 146.27 \mathrm{~km}^{2}$ and $4.11 \mathrm{~km}^{2}$ respectively. Soils types in the drainage area are sandy clay loam $(92.51 \%)$, sandy loam $(6.84 \%)$, and clay $(0.65 \%) . \mathrm{CN}$ and Initial abstraction parameter values generated based on above LULC classification and soil type values are 70.27 and 2.89 .

\subsection{SIMULATED RAINFALL DEPTH AND PEAK RUNOFF FOR CLIMATE SCENARIO RCP 4.5}

Rainfall and runoff depths under medium - low climate scenario RCP 4.5 are shown in figure $4-11$. Rainfall depths projected for the watershed in 2030, 2040, 2050 and 2060 are $38.5 \mathrm{~mm} / \mathrm{hr}, 39 \mathrm{~mm} / \mathrm{hr}, 42 \mathrm{~mm} / \mathrm{hr}$ and $46 \mathrm{~mm} / \mathrm{hr}$ respectively. Peak discharges in projected future years of 2030, 2040, 2050 and 2060 are $1771 \mathrm{~m}^{3} / \mathrm{s}, 1826 \mathrm{~m}^{3} / \mathrm{s}$, $1897 \mathrm{~m}^{3} / \mathrm{s}$ and $2200 \mathrm{~m}^{3} / \mathrm{s}$ respectively. Peak runoff values increase as rainfall depth in future periods increases. In 30 years, between 2030 and 2060, peak runoff values will increase by $24.2 \%$ for maximum rainfall depth increase of $19.5 \%$.

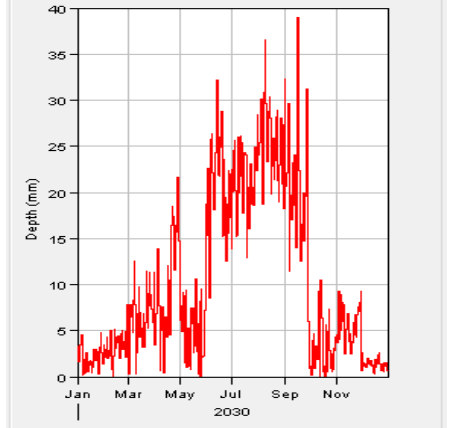

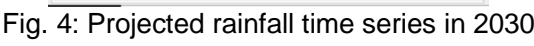

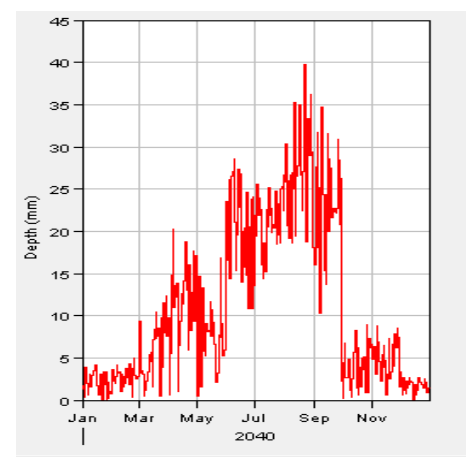

Fig. 5: Projected rainfall time series in 2040

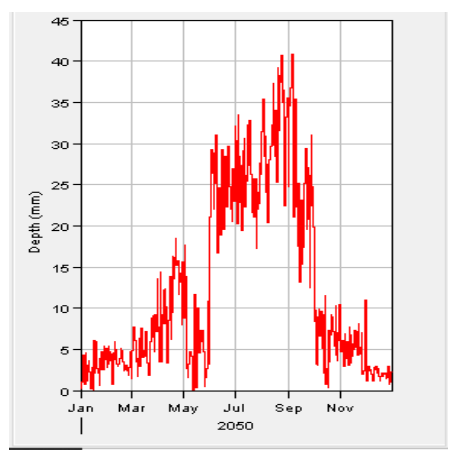

Fig 6: Projected rainfall time series in 2050

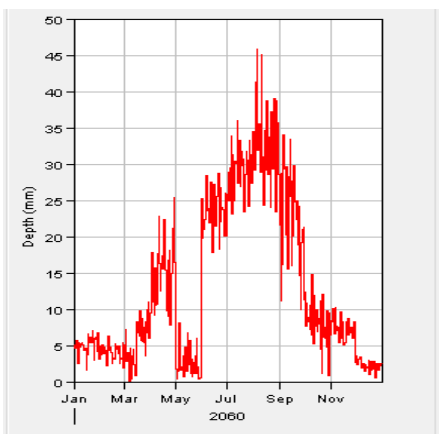

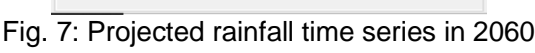




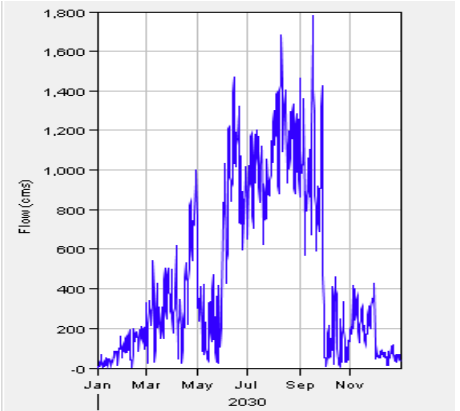

Fig. 8: Projected runoff time series in 2030

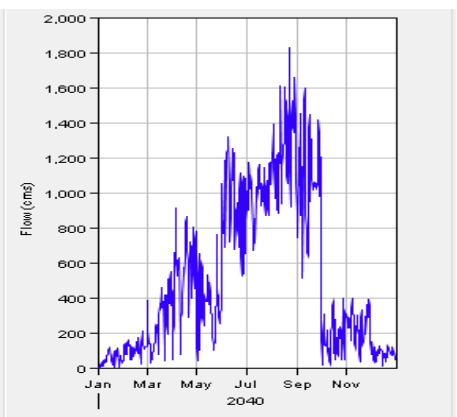

Fig. 9: Projected runoff time series in 2040

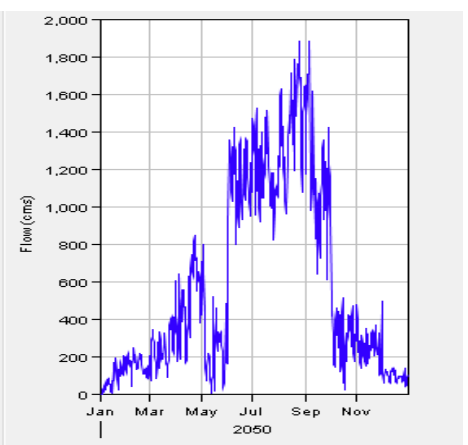

Fig. 10: Projected runoff time series in 2050

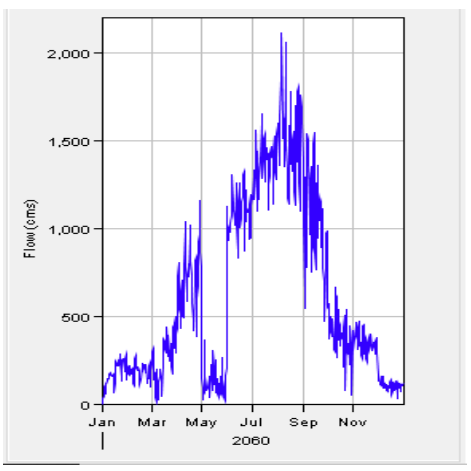

Fig. 11: Projected runoff time series in 2060

\section{Conclusion}

In this study, 20 years historic rainfall depth data collected within Ogbese watershed were used to downscale coarse GCM outputs. Rainfall depth projections for future climate scenario under RCP 4.5 show $19.5 \%$ increase between 2030 to 2060 . ArcGIS was used to delineate the catchment and to extract the $\mathrm{CN}$ parameter values for HEC-HMS model. CN and Initial abstraction parameter values were 70.27 and 2.89 respectively. The HEC-HMS model was used to simulate peak runoff with the projected rainfall depths of 38.5 $\mathrm{mm} / \mathrm{hr}, 39 \mathrm{~mm} / \mathrm{hr}, 42 \mathrm{~mm} / \mathrm{hr}$ and $46 \mathrm{~mm} / \mathrm{hr}$ in 2030, 2040, 2050 and 2060 respectively. The peak discharge values projected for these years are $1771 \mathrm{~m}^{3} / \mathrm{s}, 1826 \mathrm{~m}^{3} / \mathrm{s}, 1897$ $\mathrm{m}^{3} / \mathrm{s}$ and $2200 \mathrm{~m}^{3} / \mathrm{s}$ respectively.

\section{REFERENCES}

Akinbile, C.O. and Olatunji, O. (2018). Quality assessment and classification of Ogbese river using water quality index (WQI) tool. Sustainable Water Resources Management, 4: 10231030.

Allen, M. R. and Ingram, W. J. (2002). Constraints on future changes in climate and the hydrologic cycle. Nature, 419, 224-232.

Babel, M.S., Bhusal, S.P., Wahid, S.M. and Agarwal, A. (2014). Climate change and water resources in the Bagmati River Basin, Nepal. Theor Appl Climatol 115, 639-654.

Bai, Y., Zhang, Z. \& Zhao, W. (2019). Assessing the impact of climate change on flood events using HEC-HMS and CMIP5. Water Air Soil Pollut 230, 119.

Ebele, N. E. and Emodi, N. V. (2016). Climate change and its impact in Nigerian economy. Journal of Scientific Research \& Reports, 10(6), 1-13.

Elisha, I. et al. (2017). Evidence of climate change and adaptation strategies among grain farmers in Sokoto State, Nigeria. IOSR Journal of Environmental Science, Toxicology and Food Technology, 11(3), 1-7.

Haider, H. (2019). Climate change in Nigeria: Impacts and responses. K4D Helpdesk Report 675. Brighton, UK: Institute of Development Studies.

Hoar, T and Nychka, D. (2008). Statistical downscaling of the community climate system model (CCSM) monthly temperature and precipitation projections. White paper preprint, Institute for Mathematics Applied to Geosciences/National Center for Atmospheric Research, Boulder, CO 80307.

Idowu, A.A., Ayoola, S.O., Opele A.I and Ikenweiwe N.B. (2011). Impact of Climate Change in Nigeria. Iranica Journal of Energy $\mathcal{E}$ Environment 2 (2): 145-152.

Ingram, W. (2016). Extreme precipitation: increases all round. Nat. Clim. Change 6(5), 443-444.

Meenu, R., Rehana, S., \& Mujumdar, P. P. (2013). Assessment of hydrologic impacts of climate change in Tunga-Bhadra river basin, India with HEC-HMS and SDSM. Hydrological Processes, 27(11), 1572-1589.

Obioha, E. (2008) Climate change, population drift and violent conflict over land resources in North Eastern Nigeria. J. Hum. Ecol., 23 (4), 311-324

Okon, E.M., Falana, B.M., Solaja, S.O., Yakubu, S.O., Alabi, O.O., Okikiola, B.T., Awe, T.E., Adesina, B.T., Tokula, B.E., Kipchumba, A.K. and Edeme. A.B. (2021). Systematic review of climate change impact research in Nigeria: implication for sustainable development, Heliyon, 7(9).

Olaniyi, O. A. et al. (2013). Review of climate change and its effect on Nigeria ecosystem. International Journal of African and Asian Studies, 1,57

Olivera, F and Maidment, D. (1999). Geographic Information Systems (GIS)-Based Spatially Distributed Model for Runoff Routing. Water Resources Research 35, (10).

Oloruntade, A., Oguntunde, P and Mogaji, K. (2020). Evaluation of Two Global Rainfall Models for Water Resources Planning and Management in Nigeria. FUOYE Journal of Engineering and Technology. 5(2) 
Oyelami, A.C., Ojo, A.O., Aladejana, J.A and Agbede, O.O. (2013) Assessing the effect of a dumpsite on groundwater quality: a case study of Aduramigba estate within Osogbo metropolis. J Environ Earth Sci 3(1),120-131.

Ragatoa, D.S., Ogunjobi, K. O., Klutse, N.A.B., Okhimamhe, A.A and Eichie, J.O. (2019). A change comparison of heat wave aspects in climatic zones of Nigeria. Environ. Earth Sci., 78 (4), 111.

Sipayung, S. B., Nurlatifah, A., Siswanto, B and Slamet, L. S. (2018). Analysis of climate change impact on rainfall pattern of Sambas district, West Kalimantan. IOP Conf. Series: Earth and Environmental Science. 149.012029

Storch, H. V., Zorita, E and Cusbasch, U. (1993). Downscaling of global climate change estimates to regional scales: An application to Iberian rainfall in winter time. Journal of Climate, (61), 161- 1171.

Tabari, H. (2020). Climate change impact on food and extreme precipitation increases with water availability. Scientific Reports, 10, 13768.

Trenberth, K. E. (1998) Atmospheric Moisture Residence Times and Cycling: Implications for Rainfall Rates and Climate Change. Berlin: Springer.

Trenberth, K. E., Dai, A., Rasmussen, R. M. and Parsons, D. B. (2003) The changing character of precipitation. Bull. Am. Meteorol. Soc., $84,1205-1217$.

United States Army Corps of Engineers. (2000). HEC-HMS hydrologic modeling system users' manual. Hydrologic Engineering Center, Davis, California.

Williams, S. E., Bolitho, E. E and Fox, S. (2003) Climate Change in Australian Tropical Rainforests: An Impending Environmental Catastrophes. Royal Society Publishing

World Bank Report. (2019). Building Climate Resilience: Experience from Nigeria. https://www.worldbank.org/en/results/2019/04/18/buildingclimate-resilience-from-nigeria. 